$\begin{array}{cc}\text { ACADEMIA ROMÂNĂ } & \text { Rev. Roum. Chim., } \\ \text { Revue Roumaine de Chimie } & \text { 2019, 64(2), 173-181 } \\ \text { http://web.icf.ro/rrch/ } & \text { Doi: } 10.33224 / \text { rrch.2019.64.2.07 }\end{array}$

\title{
STUDY OF CHEMISTRY OF CR(VI)/Cr(III) BIOSORPTION FROM BATCH SOLUTIONS AND ELECTROPLATING INDUSTRIAL EFFLUENT USING CYANOBACTERIA SPIRULINA PLATENSIS
}

\author{
Nikita YUSHIN, ${ }^{\mathrm{a}, \mathrm{b}}$ Inga ZINICOVSCAIA, ${ }^{\mathrm{a}, \mathrm{c}, \mathrm{d},{ }^{*}}$ Liliana CEPOI, ${ }^{\mathrm{e}}$ Tatiana CHIRIAC \\ and Tatiana MITINA ${ }^{\mathrm{d}}$ \\ ${ }^{a}$ Joint Institute for Nuclear Research, Joliot-Curie Str., 6, 1419890 Dubna, Russia \\ ${ }^{\mathrm{b}}$ Dubna University, 19 Universitetskaya Str., 141982 г. Dubna, Russia \\ ${ }^{c}$ Horia Hulubei National Institute for R\&D in Physics and Nuclear Engineering, \\ 30 Reactorului Str. MG-6, Bucharest - Magurele, Roumania \\ ${ }^{\mathrm{d}}$ The Institute of Chemistry of the Academy of Sciences of Moldova, 3, Academiei Str., 2028 Chisinau, R. Moldova \\ ${ }^{\mathrm{e}}$ Institute of Microbiology and Biotechnology of the Academy of Science of Moldova, 1, Academiei Str., 2028 Chisinau, R. Moldova
}

The biosorption of $\mathrm{Cr}(\mathrm{III})-\mathrm{Cr}(\mathrm{VI})$ from aqueous solutions on dry Spirulina platensis biomass was tested under laboratory conditions as a function of $\mathrm{pH}$, initial metal ion concentration, biomass dosage, time and temperature. Optimum adsorption $\mathrm{pH}$ values of $\mathrm{Cr}(\mathrm{III})$ and $\mathrm{Cr}(\mathrm{VI})$ were determined as 3.0 and 2.0, respectively. The Langmuir adsorption isotherm model fit well the sorption equilibrium of the experimental data obtained for $\mathrm{Cr}(\mathrm{III})$, while Freundlich isotherm fit better data obtained for $\mathrm{Cr}(\mathrm{VI})$. The kinetic data were best described using the pseudo second-order kinetic model $\left(\mathrm{R}^{2}>0.99\right)$. The adsorption process was exothermic and the values of thermodynamic parameters of the process were calculated. Spirulina platensis biomass was also used as a biosorbent for the removal of $\mathrm{Cr}(\mathrm{VI})$ from electroplating industry effluent as a function of biosorbent dosage and contact time.

\section{INTRODUCTION}

Nowadays contamination of the environment by chromium has become a major area of concern. Chromium is present in the environment in several forms, the most common forms being $\mathrm{Cr}$ (III) and $\mathrm{Cr}(\mathrm{VI}) .{ }^{1} \mathrm{Cr}(\mathrm{VI})$ and $\mathrm{Cr}(\mathrm{III})$ are characterized by different physiochemical behavior, mobility and toxicity. ${ }^{2} \mathrm{Cr}(\mathrm{III})$ is an important microelement and its deficiency causes disturbance to the glucose and lipids metabolism in humans and animals. ${ }^{1}$ At the same time $\mathrm{Cr}(\mathrm{VI})$ is a known carcinogen, which can cause a number of noxious human health effects like skin rashes, upset stomachs, respiratory problems, weakened immune system. ${ }^{2}$
The large-scale use of chromium in metallurgical, pigment and dye, textiles, tanning, and electroplating operations make these industries potential sources of chromium pollution. ${ }^{3}$ Chromium in industrial wastewaters is mainly in the form of the hexavalent form and the most practiced method of its removal involves reduction of $\mathrm{Cr}(\mathrm{VI})$ into $\mathrm{Cr}(\mathrm{III})$ followed by $\mathrm{Cr}(\mathrm{OH})_{3}(\mathrm{~s})$ precipitation. ${ }^{2,3}$ However, there is evidence that $\mathrm{Cr}(\mathrm{OH})_{3}$ may itself be oxidized to $\mathrm{Cr}(\mathrm{VI})$, leading to contamination of natural waters. ${ }^{4}$ Other techniques for chromium ions removal from industrial effluents include adsorption, ion-exchange, flotation, electrolysis, etc. ${ }^{2,5}$ High chemicals and energy consumption and large volume of sludge generation make such processes costly and ineffective. ${ }^{2}$

\footnotetext{
*Corresponding author: zinikovskaia@mail.ru
} 
Biosorption of metal ions by metabolically inactive microbial biomass is an innovative and alternative technology for removal of these pollutants from industrial effluents. ${ }^{6}$ This technique has advantages over the conventional methods, among which are: no production of chemical sludge, high selectivity, easiness to operate and effectiveness in the treatment of large volumes of wastewaters containing pollutants in low concentrations. ${ }^{3,4,7}$

Among the organisms, cyanobacteria are gaining increasing attention in biosorption studies because of their low cost and high biosorption capacity. Spirulina biomass was extensively used in biosorption studies, including for chromium ions removal. For example, Jagiełlo et al. $^{3}$ studied the effect of $\mathrm{pH}$ and $\mathrm{Cr}$ (III) concentration on $\mathrm{Cr}$ (III) biosorption by Spirulina sp. Chojnacka and coauthors ${ }^{1}$ used four different morphological forms of Spirulina sp. biomass to study the process of Cr(III) biosorpion. Gagrai et al. ${ }^{2}$ investigated the role of functional groups on the Spirulina sp. cell wall in $\mathrm{Cr}(\mathrm{VI})$ reduction to $\mathrm{Cr}(\mathrm{III})$ form. Finocchio et al. ${ }^{4}$ studied the effect of biomass methylation on $\mathrm{Cr}(\mathrm{VI})$ adsorption by Spirulina platensis biomass.

The aim of the present study was to examine the efficiency of cyanobacteria Spirulina platensis biomass as a biosorbent for the removal of $\mathrm{Cr}(\mathrm{III}) / \mathrm{Cr}(\mathrm{VI})$ ions from batch solutions. Equilibrium and kinetic studies were performed to describe the adsorption process. To determine the best biosorption conditions, factors, such as $\mathrm{pH}$, temperature, adsorption time, initial metal concentration, and sorbent dosage were examined. The process of $\mathrm{Cr}(\mathrm{VI})$ removal from industrial effluent was studied as well.

\section{EXPERIMENTAL}

\section{Reagents and materials}

All the chemicals used for biosorption experiments were purchased from Sigma-Aldrich and were of analytical grade.

\section{Industrial effluent}

The industrial effluent containing chromium(VI) in concentration $34 \mathrm{mg} / \mathrm{L}(\mathrm{pH}$ 4) was taken from electroplating units. Industrial effluent was collected directly after the electroplating process. Current treatment schemes of industrial effluent for metal removal include a complex of chemical methods.

\section{Biosorbent}

Spirulina platensis (S. platensis) biomass in a dried form was purchased from "Biosolar MSU" company (Moscow, Russia).

\section{Batch experiment}

The experiments were conducted in $100 \mathrm{~mL}$ Erlenmeyer flasks containing $50 \mathrm{~mL}$ of $\mathrm{Cr}(\mathrm{III}) / \mathrm{Cr}$ (VI) synthetic solutions. The flasks were shaken on a shaker incubator at a constant rate of $120 \mathrm{rpm}$. To investigate the effect of $\mathrm{pH}$, sorbent dosage, initial metal concentration, temperature and contact time, different $\mathrm{pH}(2.0-6.0)$, sorbent dosage $(0.1,0.2,0.3,0.4,0.5$, $0.7,1.0 \mathrm{~g})$ initial metal concentration $(10-200 \mathrm{mg} / \mathrm{L})$, time $(5$, $7,10,15,30,45,60,120 \mathrm{~min})$ and temperature $(293,303,313$, $323 \mathrm{~K})$ were used. After the experiment the biomass was removed by filtration and the obtained solution was used for further analysis. All experiments were carried out in triplicate and the average value of obtained experimental values was used for calculations.

\section{Industrial effluent experiment}

The effect of biosorbent dosage (0.5-2.0 g) and contact time (5-60 min) on $\mathrm{Cr}(\mathrm{VI})$ removal from industrial effluent was examined. In all experiments the working volume was $50 \mathrm{~mL}$.

Chromium concentration in the solution was determined by applying atomic absorption spectrometry (iCe 3000 series) with electrothermal atomization at a resonance line of $357.9 \mathrm{~nm}$.

\section{Data evaluation}

The biosorption of $\mathrm{Cr}(\mathrm{III}) / \mathrm{Cr}(\mathrm{VI})$ by Spirulina platensis biomass was evaluated using the following parameters, which were calculated from experimental results:

(a) amount of heavy metals retained on mass unit of spirulina biomass (q, $\mathrm{mg} / \mathrm{g})$ :

$$
q=\frac{\left(c_{i}-c_{f}\right) V}{m}
$$

(b) efficiency of heavy metals removal (R, \%):

$$
R=\frac{C_{i}-C_{f}}{C_{i}} \cdot 100 \%
$$

where $q$ is the amount of metal ions adsorbed on the biosorbent, $\mathrm{mg} / \mathrm{g} ; V$ is the volume of solution, $\mathrm{L} ; C_{i}$ is the initial concentration of metal in $\mathrm{mg} / \mathrm{L}, C_{f}$ is the final metal concentration in the solution, $\mathrm{mg} / \mathrm{L}$, and $m$ is the mass of sorbent, g.

The experimental equilibrium data were modelled using two isotherm models, namely Langmuir and Freundlich. According to the Langmuir isotherm model, the biosorption process occurs at specific homogeneous sites on the biosorbent surface, until a complete monolayer is formed. The linear form of equation of the Langmuir isotherm is expressed as follows:

$$
\frac{1}{q_{e}}=\frac{1}{q_{\max }}+\frac{1}{b q_{\max } C_{e}}
$$

where $q_{e}(\mathrm{mg} / \mathrm{g})$ is the amount adsorbed at the equilibrium concentration $C_{e}, q_{m}(\mathrm{mg} / \mathrm{g})$ is the Langmuir constant representing the maximum monolayer adsorption capacity and $b(\mathrm{~L} / \mathrm{mol})$ is the Langmuir constant related to energy of adsorption.

The dimensionless separator factor $\left(\mathrm{R}_{\mathrm{L}}\right)$ is the essential characteristic of this model, which is defined by:

$$
R_{L}=\frac{1}{1+b C_{i}}
$$


where $b$ is the Langmuir constant and $C_{i}$ is the initial concentration of metal in solution. The value of $R_{L}$ indicates the shape of the isotherms to be either irreversible $\left(R_{L}=0\right)$, favorable $\left(0<\mathrm{R}_{\mathrm{L}}<1\right)$ or unfavorable $\left(\mathrm{R}_{\mathrm{L}}>1\right)$.

The Freundlich isotherm is an empirical equation, which assumes a heterogeneous biosorption system with different active sites. The liniar form of Freundlich equation is written as follows:

$$
\ln q_{e}=\ln K_{F}+\frac{1}{n} \ln C_{e}
$$

where: $K_{F}$ and $1 / n$ are Freundlich constants, associated with adsorption capacity and adsorption intensity, respectively.

For the kinetic modelling, two kinetics models have been used to fit the experimental data. The pseudo-first-order Lagergren model expressed as:

$$
\log \left(q_{e}-q\right)=\log q_{e}-\frac{K_{a}}{2.303} t
$$

where $q$ and $q_{e}$ are the adsorbed amounts $(\mathrm{mg} / \mathrm{g})$ at time $(t)$ (min) and at equilibrium time, respectively, $k_{a}\left(\min ^{-1}\right)$ is the rate constant of the first-order biosorption.

The pseudo-second-order kinetics can be expressed:

$$
\frac{1}{q}=\frac{1}{K_{b} q_{e}^{2}}+\frac{t}{q_{e}}
$$

where $q$ and $q_{e}$ are the adsorbed amounts $(\mathrm{mg} / \mathrm{g})$ at time $(t)$ ( $\min )$ and at equilibrium time, respectively, $k_{b}\left(\mathrm{~g} / \mathrm{mg}^{*} \mathrm{~min}\right)$ is the rate constant of the second-order biosorption.

The straight lines in the graphical representation of $\log$ $\left(\mathrm{q}_{\mathrm{e}}-\mathrm{q}\right) v s . \mathrm{t}$ for the pseudo-first order kinetics model, and $\mathrm{t} / \mathrm{q} v s$. $\mathrm{t}$ for the pseudo-second order kinetics model highlight the applicability of these models in the describing of biosorption kinetics and will allow the calculation of characteristic kinetics parameters $\left(\mathrm{K}_{\mathrm{a}}, \mathrm{K}_{\mathrm{b}}\right.$ and $\left.\mathrm{q}_{\mathrm{e}}\right)$ from the slopes and intercepts of the linear plots.

The thermodynamic parameters, free energy change $\left(\Delta \mathrm{G}^{\circ}\right)$, enthalpy change $\left(\Delta \mathrm{H}^{\circ}\right)$ and entropy change $\left(\Delta \mathrm{S}^{\circ}\right)$ were calculated to evaluate the thermodynamic feasibility of the process and to confirm the nature of the adsorption process. The values of enthalpy $\left(\Delta \mathrm{H}^{\circ}\right)$ and entropy $\left(\Delta \mathrm{S}^{\circ}\right)$ were obtained from the slope and intercept of $\ln K_{d} v s$. $1 / T$ plots, which are calculated by a curve-fitting program.

$$
\ln K_{d}=\frac{\Delta S^{0}}{R}-\frac{\Delta H^{0}}{R T}
$$

where $\left(\Delta \mathrm{H}^{\circ}\right),\left(\Delta \mathrm{S}^{\circ}\right), \mathrm{T}$ (in Kelvin) and $\mathrm{R}$ are the enthalpy, entropy, temperature and the gas constant, respectively.

The distribution coefficient $\left(\mathrm{K}_{\mathrm{d}}\right)$ was calculated using the following formula:

$$
K_{d}=\frac{\left(c_{0}-c_{e}\right) V}{m C_{e}}
$$

where $\mathrm{C}_{0}$ and $\mathrm{Ce}$ are initial and equilibrium chromium concentrations $(\mathrm{mg} / \mathrm{L}), \mathrm{V}$ is the volume of the solution $(\mathrm{mL})$, and $\mathrm{m}$ is the mass of the biosorbent $(\mathrm{g})$.

The Gibbs free energy, $\left(\Delta \mathrm{G}^{\circ}\right)$, of specific adsorption was calculated from the equation:

$$
\Delta G^{0}=\Delta H^{0}-T \Delta S^{0}
$$

\section{RESULTS AND DISCUSSION}

\section{Effect of pH and sorbent dosage}

$\mathrm{pH}$ is the most important parameter affecting the solution chemistry of chromium as well as the distribution of functional groups of biomass species. ${ }^{9}$ The effect of solution $\mathrm{pH}$ on $\mathrm{Cr}$ (III) and $\mathrm{Cr}(\mathrm{VI})$ sorption was evaluated within the $\mathrm{pH}$ range from 2.0 to 6.0. The process of chromium biosorption was studied till $\mathrm{pH} 6$ as under alkaline conditions weakly soluble $\mathrm{Cr}(\mathrm{OH})_{3}$ and $\mathrm{Cr}(\mathrm{OH})_{4}{ }^{-}$ forms are formed ${ }^{3}$. As it can be seen from Fig. 1 the $\mathrm{Cr}$ (III) uptake reached the maximum $74 \%$ at $\mathrm{pH} 3.0$ and the decrease of metal removal capacity was observed at $\mathrm{pH}$ range 4.0-6.0. The high chromium biosorption can be explained by electric attractive interactions between the positive chromium ions $\mathrm{Cr}(\mathrm{OH})^{2+}, \mathrm{Cr}(\mathrm{OH})_{2}{ }^{+}$and $\mathrm{Cr}(\mathrm{III})$ and algal cell wall functional groups. ${ }^{10}$

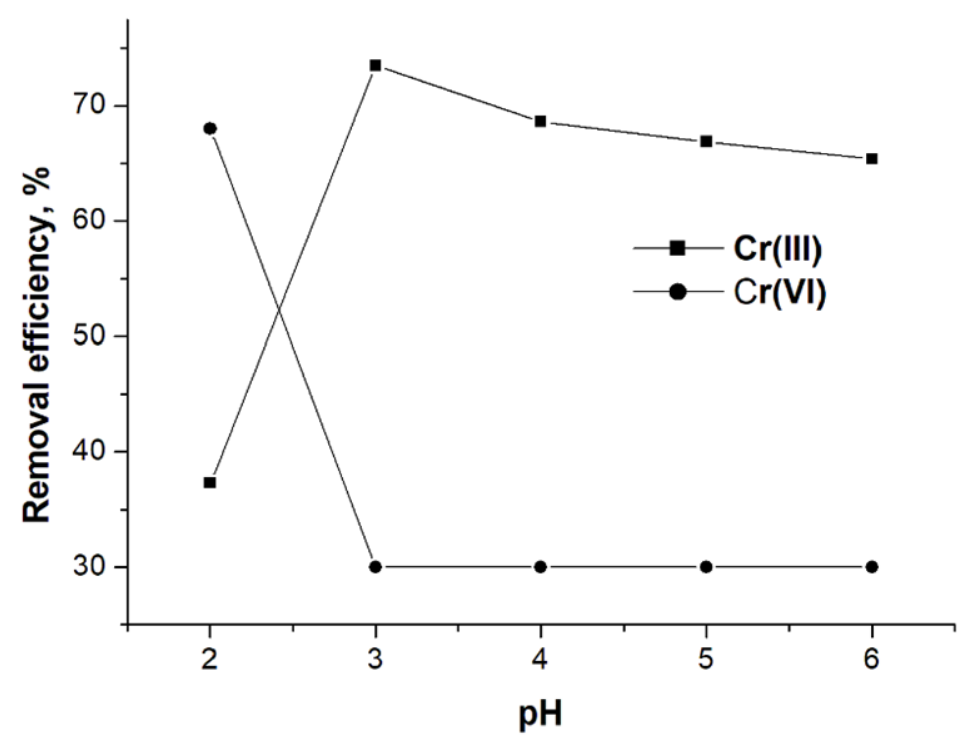

Fig. 1 - Removal of Cr(III) and Cr(VI) ions at different initial pH (T $293 \mathrm{~K} ; C_{i} 10 \mathrm{mg} / \mathrm{L}$; sorbent dosage $0.5 \mathrm{~g}$; adsorption time $1 \mathrm{~h}$ ). 


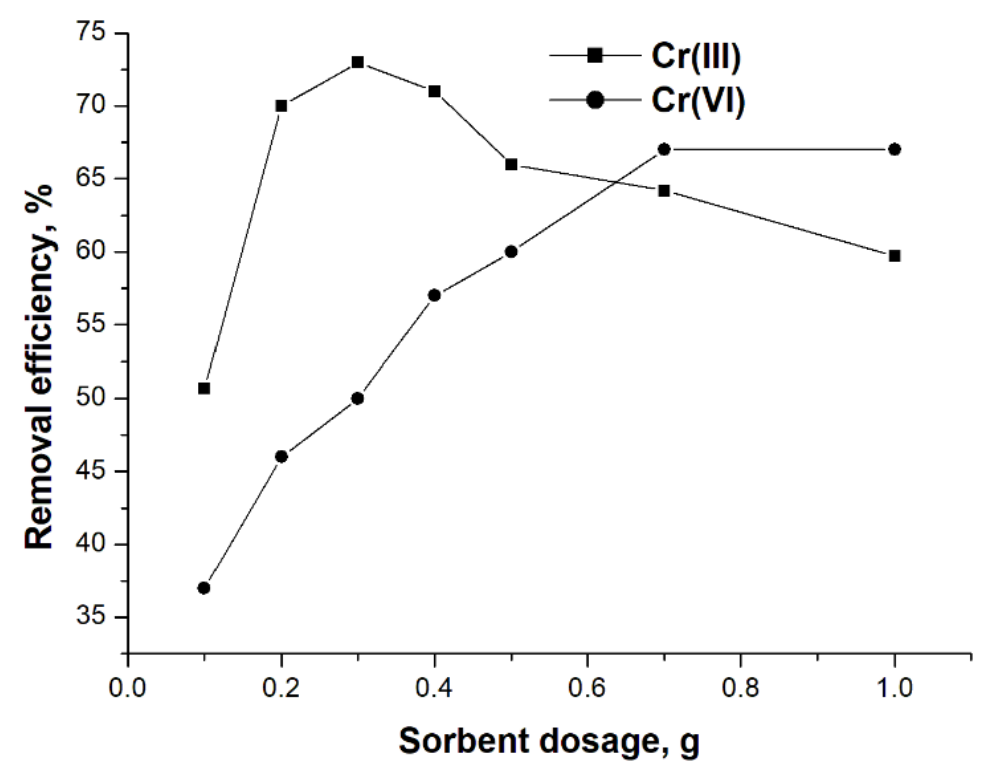

Fig. 2 - Effect of biosorbent dose on biosorption capacity and removal efficiency of chromium ions by $S$. platensis biomass (T $293 \mathrm{~K} ; \mathrm{C}_{0} 10 \mathrm{mg} / \mathrm{L}$; adsorption time $1 \mathrm{~h}, \mathrm{pH} 2 \mathrm{Cr}(\mathrm{VI}) / \mathrm{pH} 3$ (Cr(III)).

Maximum Cr(III) sorption (74\%) in Gagrai et al. study ${ }^{2}$ was observed at initial $\mathrm{pH}$ 4.0. Jagieło et $a .^{3}$ showed the $\mathrm{pH} 3.0$ was optimal for $\mathrm{Cr}(\mathrm{III})$ removal by Spirulina sp.

The maximum $\mathrm{Cr}(\mathrm{VI})$ removal $(0.73 \mathrm{mg} / \mathrm{g})$ was achieved at $\mathrm{pH} 2.0$, due to the protonation of functional groups on the cyanobacteria surface and presence of chromium in solution in anionic forms $\mathrm{HCrO}_{4}^{-}$and $\mathrm{Cr}_{2} \mathrm{O}_{7}{ }^{2-} .{ }^{12}$ At higher $\mathrm{pH}$ values, the overall surface charge on cell wall becomes negative and biosorption decreases. ${ }^{13}$ Amine groups may play an important role in $\mathrm{Cr}(\mathrm{VI})$ ions binding. ${ }^{2}$ Donmez and co-authors ${ }^{9}$ performed experiments on $\mathrm{Cr}(\mathrm{VI})$ biosorption by Chlorella vulgaris, Scenedesmus obliquus and Synechocystis $s p$ biomass and showed maximum $\mathrm{Cr}(\mathrm{VI})$ uptake at $\mathrm{pH}$ 2.0. The maximum biosorption of $\mathrm{Cr}(\mathrm{VI})$ (80\%) from the medium occurs at $\mathrm{pH} 2.0$ by $S$. platensis during $48 \mathrm{~h}$ experiment. ${ }^{12}$

Fig. 2 illustrates the effect of the biosorbent dose on the $\mathrm{Cr}(\mathrm{III}) / \mathrm{Cr}(\mathrm{VI})$ biosorption from solutions. The experiments were performed at optimal $\mathrm{pH}$ values determined in previous experiments. The dependence in Fig. 2 shows that $\mathrm{Cr}(\mathrm{VI})$ removal efficiency varied from $37 \%$ to $67 \%$ for an increase of the biosorbent dosage from 0.1 to $1.0 \mathrm{~g}$. The biosorption was constant at sorbent dosage 0.7 and $1.0 \mathrm{~g}$, that could be explained by the decrease of surface area for biosorption due to formation of aggregates of biomass at higher doses and competition of the ions for the available sites ${ }^{13}$.

In case of $\mathrm{Cr}$ (III) maximum metal removal was achieved at sorbent dosage $0.3 \mathrm{~g}$ after some reduction was observed. The observed trend can be attributed to the fact that at higher sorbent quantities a partial aggregation of biomass occurs, which determined a decrease in the effective surface area for biosorption. ${ }^{14}$ Therefore, the optimum sorbent dose for further experiments was selected as $0.3 \mathrm{~g}$ for $\mathrm{Cr}(\mathrm{III})$ and $0.7 \mathrm{~g}$ for $\mathrm{Cr}(\mathrm{VI})$.

\section{Effect of time and kinetics of sorption}

Contact time highly influences the biosorption process. Biosorption can be presented as a two-stage process, in which rapid sorption of metal ions to the surface groups of the biomass occurs at the first phase followed by diffusion of metal to internal binding sites on the biomass in the second phase. ${ }^{13}$ Fig. 3 shows the effect of contact time on the biosorption of $\mathrm{Cr}(\mathrm{III})$ and $\mathrm{Cr}(\mathrm{VI})$ ions by S. platensis biomass.

The results indicated rapid sorption of $\mathrm{Cr}$ (III) in first $30 \mathrm{~min}$ of sorbent- sorbate interaction after that the equilibrium was reached. In $30 \mathrm{~min} 70 \%$ of chromium ions were removed from solution. The maximum amount of $\mathrm{Cr}(\mathrm{VI})$, which constitute $62 \%$ was removed in $45 \mathrm{~min}$ of interaction.

In order to investigate the process of $\mathrm{Cr}(\mathrm{III}) / \mathrm{Cr}(\mathrm{VI})$ ions biosorption by $S$. platensis biomass, two kinetic models, pseudo-first order and pseudo second order models, were used to analyze the experimental data. The slope and intercept of plot of $\log \left(\mathrm{q}_{\mathrm{e}^{-}}-\mathrm{q}_{\mathrm{t}}\right)$ versus $\mathrm{t}$ were used to obtain the first-order rate constant $\mathrm{k}_{\mathrm{a}}$ and equilibrium uptake $\mathrm{q}_{\mathrm{e}}$. The pseudo second-order biosorption rate constant $\left(\mathrm{k}_{\mathrm{b}}\right)$ and $\mathrm{q}_{\mathrm{e}}$ values were determined from the slope and intercept of the plot of $\mathrm{t} / \mathrm{q}_{\mathrm{t}}$ against time, $\mathrm{t}$ (Fig. 4). 


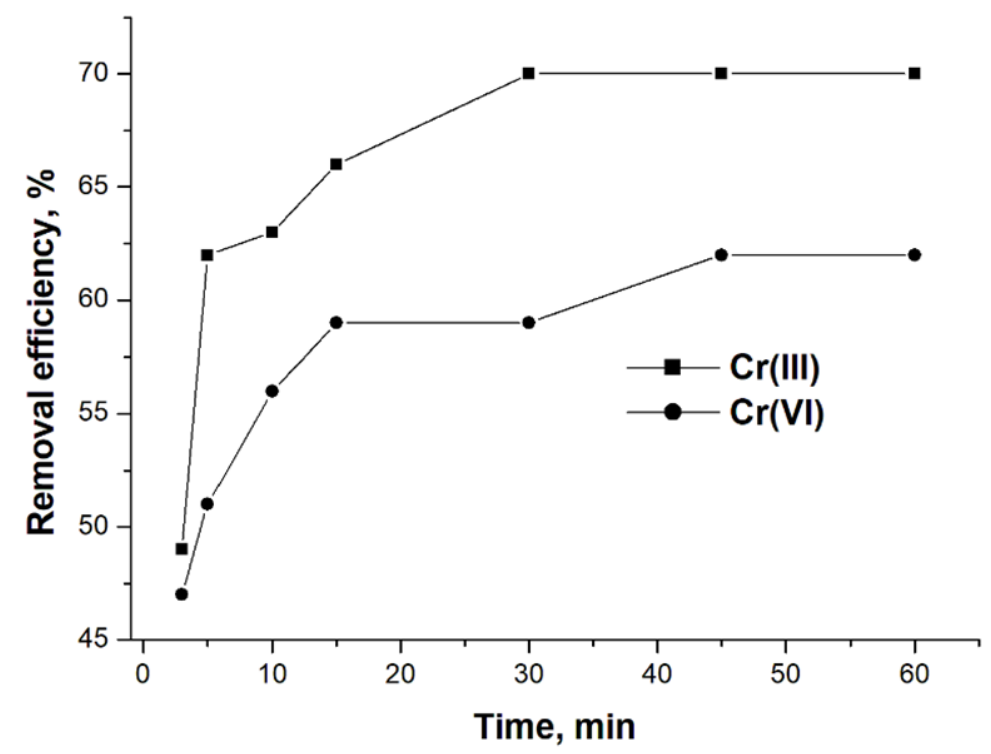

Fig. 3 - Effect of contact time on the sorption of chromium ions by $S$. platensis biomass (T $293 \mathrm{~K} ; \mathrm{C}_{0} 10 \mathrm{mg} / \mathrm{L} ; \mathrm{pH} 2 \mathrm{Cr}(\mathrm{VI}) / \mathrm{pH} 3$ (Cr(III)).
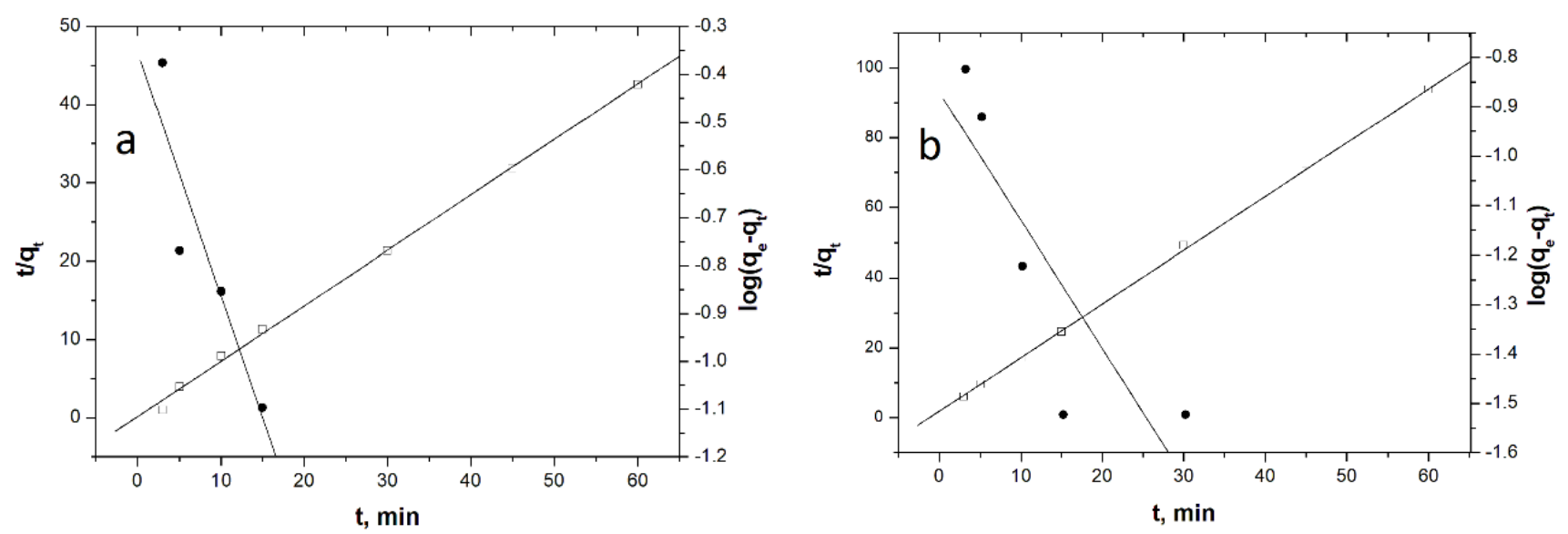

Fig. 4 - The pseudo-first- and pseudo second order plots of kinetic study of (a) $\mathrm{Cr}$ (III) and (b) $\mathrm{Cr}$ (VI) biosorption on S. platensis.

Table 1

Lagergren's pseudo-second-order model parameters

\begin{tabular}{lllll}
\hline $\mathbf{C r}(\mathbf{I I I})$ & & & & \\
\hline $\mathrm{Ce}, \mathrm{mg} / \mathrm{L}$ & $\mathrm{q}_{\mathrm{e}(\text { exp), }} \mathrm{mg} / \mathrm{g}$ & $\mathrm{q}_{\mathrm{e}(\mathrm{cal}),} \mathrm{mg} / \mathrm{g}$ & $\mathrm{k}_{\mathrm{b}}, \mathrm{g} / \mathrm{mg}^{*} \min$ & $\mathrm{R}^{2}$ \\
\hline 10 & 1.41 & 1.41 & 0.92 & 0.999 \\
\hline $\mathbf{C r}(\mathbf{V I})$ & & & & \\
\hline $\mathrm{Ce}, \mathrm{mg} / \mathrm{L}$ & $\mathrm{q}_{\text {(exp), }} \mathrm{mg} / \mathrm{g}$ & $\mathrm{q}_{\mathrm{e}(\mathrm{cal}),} \mathrm{mg} / \mathrm{g}$ & $\mathrm{k}_{\mathrm{b}}, \mathrm{g} / \mathrm{mg}^{*} \mathrm{~min}$ & $\mathrm{R}^{2}$ \\
\hline 10 & 0.64 & 0.65 & 1.56 & 0.999 \\
\hline
\end{tabular}

The correlation coefficients for the pseudo-firstorder model obtained for both forms of chromium show negative value. It can be concluded that pseudo-first-order model is not applicable to describe experimental data. The correlation coefficient, $\mathrm{R}^{2}$, for the pseudo-second-order rate equation was 0.999 for both chromium species. Parameters calculated for pseudo-second-order model are presented in Table 1.
Applicability of second order model shows that the rate controlling step in the biosorption process is the chemical interaction between $\mathrm{Cr}(\mathrm{III}) / \mathrm{Cr}(\mathrm{VI})$ ions from aqueous solution and functional groups from cyanobacteria biomass surface. ${ }^{14}$

\section{Effect of concentration and isotherm modeling}

The initial metal ion concentration remarkably influenced the equilibrium metal uptake and 
adsorption yield. The increase of chromium concentration in solution from 10 to $200 \mathrm{mg} / \mathrm{L}$ led to increase of the amount of chromium adsorbed by biomass from 1.2 to $11.2 \mathrm{mg} / \mathrm{g}$ for $\mathrm{Cr}$ (III) and from 0.6 to $9.5 \mathrm{mg} / \mathrm{g}$ for $\mathrm{Cr}(\mathrm{VI})$.

The adsorption plots of Langmuir and Freundlich isotherm model for biosorption of $\mathrm{Cr}(\mathrm{III})$ and $\mathrm{Cr}(\mathrm{VI})$ ions by $S$. platensis presented in Fig. 5. The adsorption constants evaluated from the isotherms with the correlation coefficients are given in Table 2.

The obtained values of correlation coefficients show that Langmuir model described better the $\mathrm{Cr}(\mathrm{III})$ biosorption process by $S$. platensis and $\mathrm{Cr}(\mathrm{VI})$ biosorption fits better into Freundlich isotherm. The Langmuir model is used to estimate the maximum uptake values, which could not be reached in the experiments. The determined $\mathrm{q}_{\max }$ value of $\mathrm{Cr}$ (III) by was found to be $25 \mathrm{mg} / \mathrm{g}$ and of $\mathrm{Cr}(\mathrm{VI}) 16.8 \mathrm{mg} / \mathrm{g}$.

Applicability of Langmuir and Freundlich models to the $\mathrm{Cr}(\mathrm{VI})-\mathrm{Cr}(\mathrm{III})$ biosorption indicates that both monolayer biosorption and heterogeneous energetic distribution of active sites on the surface of biosorbent are possible. The values of $\mathrm{R}_{\mathrm{L}}$ for both chromium forms were lower that 1 ( 0.5 for $\mathrm{Cr}(\mathrm{III})$ and 0.56 for $\mathrm{Cr}(\mathrm{VI})$ ), confirming the favourable biosorption of chromium ions by spirulina biomass.

Both Freundlich and Langmuir adsorption models were applicable for $\mathrm{Cr}(\mathrm{VI})$ removal by three algal species in Domnez et al. ${ }^{9}$ study. Lodi and co-authors ${ }^{10}$ showed that Langmuir model described better the $\mathrm{Cr}$ (III) biosorption process by S. platensis and $\mathrm{Cr}(\mathrm{VI})$ biosorption by $C$. vulgaris fits better into Freundlich isotherm ${ }^{13}$. Table 3 shows the maximum biosorption capacity obtained for other biosorbents.

The values of maximum biosorption capacity found in this work were comparable with values presented in the literature.

\section{Thermodynamic study}

The effect of temperature, ranging from 293 to $323 \mathrm{~K}$, on the removal of $\mathrm{Cr}(\mathrm{III})$ and $\mathrm{Cr}(\mathrm{VI})$ ions was evaluated at contact time of $60 \mathrm{~min}$. Increase of temperature from 293 to $323 \mathrm{~K}$ lead to decrease of biomass biosorption capacity from 1.025 to $0.675 \mathrm{mg} / \mathrm{g}$ for $\mathrm{Cr}$ (III) and from 0.66 to $0.49 \mathrm{mg} / \mathrm{g}$ for $\mathrm{Cr}(\mathrm{VI})$.

The thermodynamic constants namely, free energy change $\left(\Delta \mathrm{G}^{\circ}\right)$, enthalpy change $\left(\Delta \mathrm{H}^{\circ}\right)$ and entropy change $\left(\Delta \mathrm{S}^{\circ}\right)$ were calculated to evaluate the thermodynamic feasibility of the process and to confirm the nature of the adsorption process. The values of enthalpy $\left(\Delta \mathrm{H}^{\circ}\right)$ and entropy $\left(\Delta \mathrm{S}^{\circ}\right)$ were evaluated from the slope and intercept of $\ln \mathrm{K}_{\mathrm{d}} \mathrm{vs}$. $1 / \mathrm{T}$ plots (Fig. 6) and the obtained data are presented in Table 4.

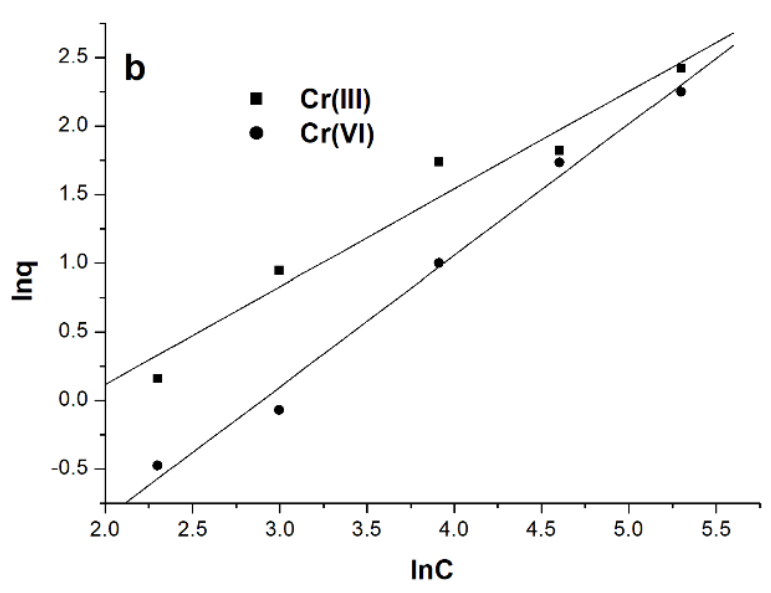

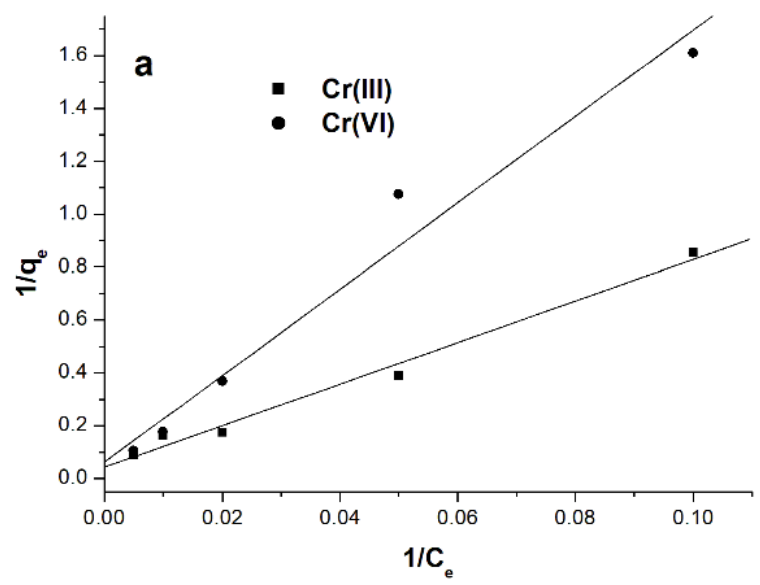

Fig. 5 - Langmuir (a) and Freundlich (b) isotherm models.

Table 2

Isotherm parameters for the biosorption of chromium ions on S. platensis biomass

\begin{tabular}{|c|c|c|c|}
\hline \multicolumn{2}{|c|}{ Langmuir model } & \multicolumn{2}{|c|}{ Freundlich model } \\
\hline \multicolumn{4}{|c|}{$\mathrm{Cr}$ (III) } \\
\hline $\mathrm{R}^{2}$ & 0.99 & $\mathrm{R}^{2}$ & 0.98 \\
\hline Q max & $25.0 \mathrm{mg} / \mathrm{g}$ & $\ln \mathrm{K}_{\mathrm{f}}$ & -1.31 \\
\hline b & 0.005 & $\mathrm{n}$ & 1.4 \\
\hline \multicolumn{4}{|c|}{$\mathrm{Cr}(\mathrm{VI})$} \\
\hline $\mathrm{R}^{2}$ & 0.985 & $\mathrm{R}^{2}$ & 0.995 \\
\hline Q max & $16.8 \mathrm{mg} / \mathrm{g}$ & $\ln \mathrm{K}_{\mathrm{f}}$ & -2.77 \\
\hline b & 0.004 & $\mathrm{n}$ & 1.04 \\
\hline
\end{tabular}


Table 3

$\mathrm{Cr}(\mathrm{VI}) / \mathrm{Cr}(\mathrm{III})$ biosorption by different type of sorbents

\begin{tabular}{|c|c|c|c|}
\hline Metal & Biosorbent & $q_{\max }, \mathbf{m g} / \mathrm{g}$ & Reference \\
\hline $\mathrm{Cr}(\mathrm{VI})$ & Chlorella vulgaris & 23 & Donmez et al. ${ }^{9}$ \\
\hline $\mathrm{Cr}(\mathrm{VI})$ & Scenedesmus obliquus & 15.6 & Donmez et al. ${ }^{9}$ \\
\hline $\mathrm{Cr}(\mathrm{VI})$ & Synechocystis sp. & 19.2 & Donmez et al. ${ }^{9}$ \\
\hline $\mathrm{Cr}(\mathrm{VI})$ & $\begin{array}{c}\text { Poly(methyl methacrylate)-grafted } \\
\text { Hyparrhenia hirta (PMMA-g-Hh) biopolymer }\end{array}$ & $4.02-19.95$ & Guyo et al. ${ }^{15}$ \\
\hline $\mathrm{Cr}(\mathrm{III})$ & $\begin{array}{l}\text { Spirulina } \mathrm{sp} . \\
\text { Sp }\end{array}$ & $38.5-185$ & Chojnacka et al. ${ }^{8}$ \\
\hline $\mathrm{Cr}(\mathrm{III})$ & Spirulina platensis & $30.1-36.8$ & Lodi et al. ${ }^{10}$ \\
\hline
\end{tabular}

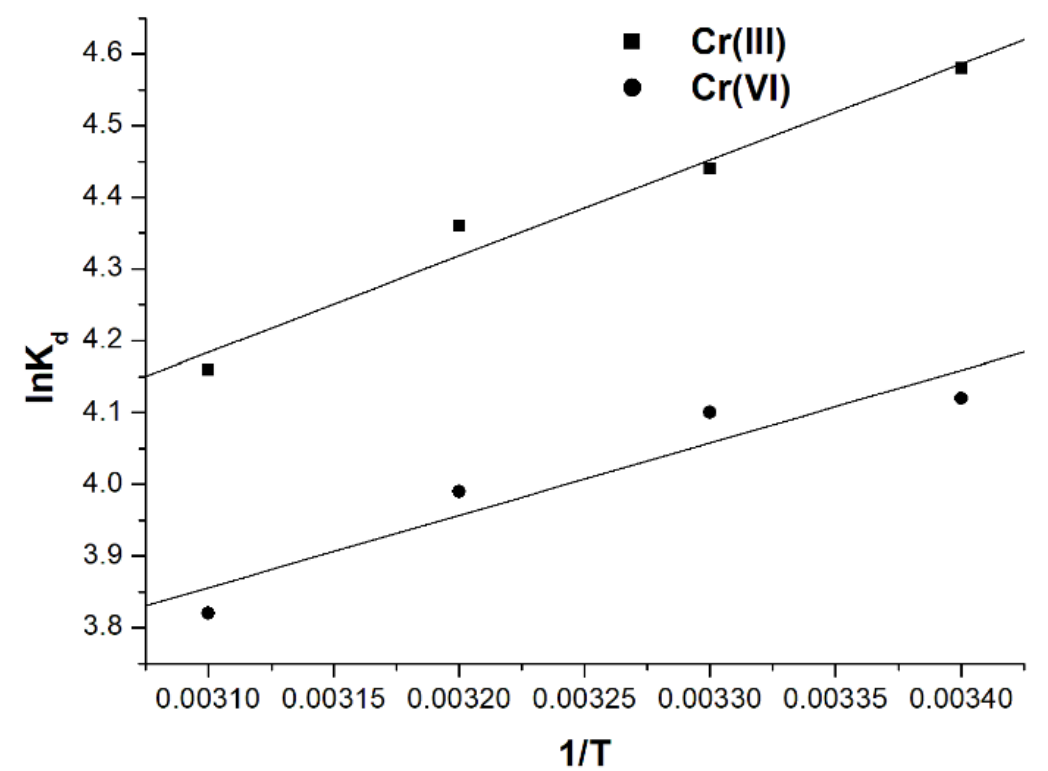

Fig. 6 - Dependence of $\operatorname{lnK}_{d}$ vs. 1/T.

Table 4

Thermodynamic parameters for $\mathrm{Cr}(\mathrm{III}) / \mathrm{Cr}(\mathrm{VI})$ biosorption on $S$. platensis

\begin{tabular}{c|c|c|c|c|c|c}
\hline Temperature, $\mathrm{K}$ & \multicolumn{2}{|c|}{$\Delta \mathrm{G}^{\circ}, \mathrm{kJ} / \mathrm{mol}$} & \multicolumn{2}{c|}{$\Delta \mathrm{H}^{\circ}, \mathrm{kJ} / \mathrm{mol}$} & \multicolumn{2}{c}{$\Delta \mathrm{S}^{\circ}, \mathrm{J} / \mathrm{mol} \cdot \mathrm{K}$} \\
\hline 293 & $\mathrm{Cr}(\mathrm{III})$ & $\mathrm{Cr}(\mathrm{VI})$ & $\mathrm{Cr}(\mathrm{III})$ & $\mathrm{Cr}(\mathrm{VI})$ & $\mathrm{Cr}(\mathrm{III})$ & $\mathrm{Cr}(\mathrm{VI})$ \\
303 & -11.24 & -9.01 & -11.1 & -8.4 & 0.35 & 2.1 \\
313 & -11.25 & -9.03 & & & & \\
323 & -11.25 & -9.05 & & & & \\
\hline
\end{tabular}

A negative value of $\Delta \mathrm{G}^{\circ}$ indicates the feasibility of the process and spontaneous nature of the biosorption. The negative values of $\Delta \mathrm{H}^{\circ}$ suggests the exothermic nature of biosorption and the positive value of $\Delta \mathrm{S}^{\circ}$ confirms the increased randomness at the solid-solution interface during biosorption.

\section{$\mathrm{Cr}(\mathrm{VI})$ removal from industrial effluent}

Upon completion of batch adsorption experiments, the efficiency of $S$. platensis biomass in the removal of $\mathrm{Cr}(\mathrm{VI})$ from industrial effluent as a function of time and sorbent dosage was evaluated. To study the effect of contact time on $\mathrm{Cr}(\mathrm{VI})$ absorption experiment was performed at sorbent dosage $0.7 \mathrm{~g}$, determined as more efficient dosage in batch experiments. The data presented in Fig. 7 show that equilibrium was reached after 45 min of interaction. However, the efficiency of $\mathrm{Cr}(\mathrm{VI})$ removal was lower than in batch experiments, that can be explained by higher chromium concentration in effluent.

Thus, to increase the efficiency of $\mathrm{Cr}(\mathrm{VI})$ ions removal the sorbent dosage was increased from 0.7 to $2.0 \mathrm{~g}$ (Fig. 8).

With the increase of sorbent dosage $\mathrm{Cr}(\mathrm{VI})$ removal increased from 50 to $72 \%$. In our previous study it was shown that at $\mathrm{Cr}(\mathrm{VI})$ was completely removed from wastewater at initial chromium concentration $9.1 \mathrm{mg} / \mathrm{L}$, sorbent dosage $1.0 \mathrm{~g}$ during one hour. ${ }^{16}$ 


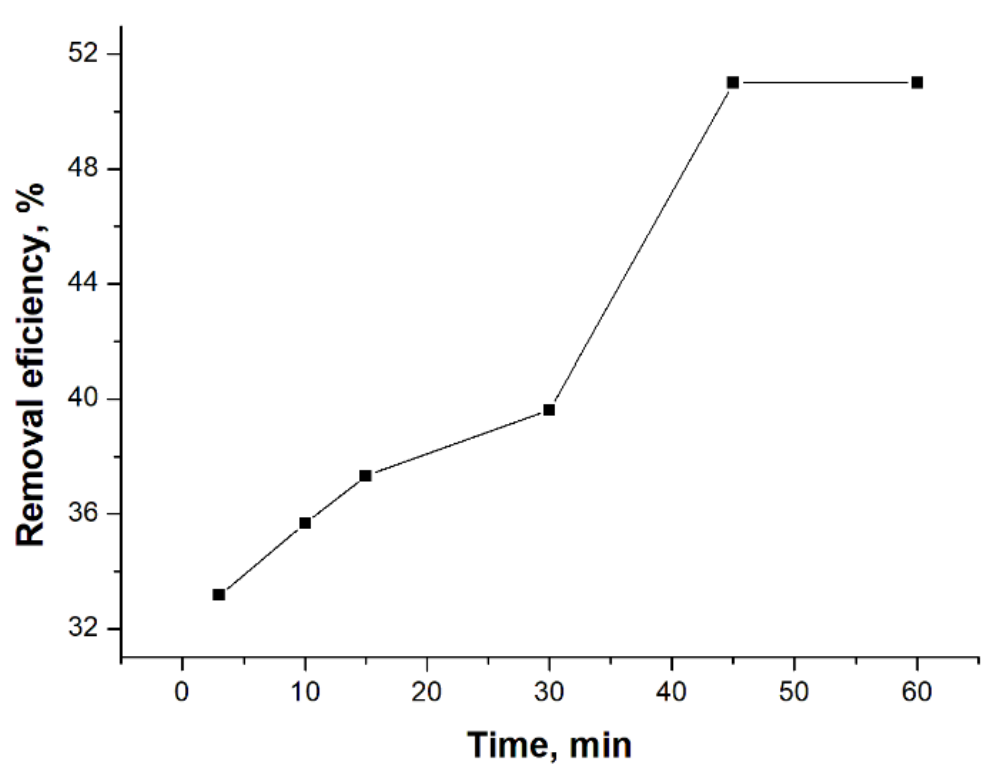

Fig. 7 - Effect of contact time on the sorption of $\mathrm{Cr}(\mathrm{VI})$ ions by $S$. platensis biomass (T $293 \mathrm{~K} ; \mathrm{C}_{0} 27 \mathrm{mg} / \mathrm{L}$; sorbent dosage $0.7 \mathrm{~g}, \mathrm{pH}$ 4).

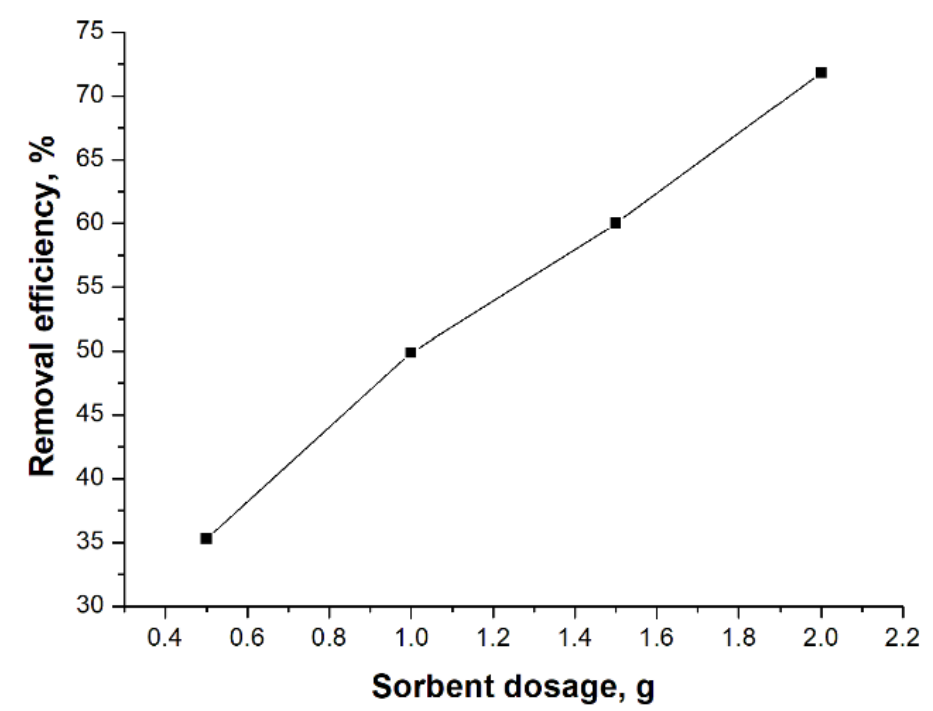

Fig. 8 - Effect of biosorbent dose on removal efficiency of $\mathrm{Cr}(\mathrm{VI})$ ions by $S$. platensis biomass (T $293 \mathrm{~K} ; \mathrm{C}_{0} 10 \mathrm{mg} / \mathrm{L}$; adsorption time $45 \mathrm{~min}, \mathrm{pH} 4$ ).

\section{CONCLUSION}

Spirulina platensis can be efficiently applied for $\mathrm{Cr}(\mathrm{III}) / \mathrm{Cr}(\mathrm{VI})$ biosorption from batch solutions and industrial effluents. The maximum biosorption capacity of $\mathrm{Cr}$ (III) $25.0 \mathrm{mg} / \mathrm{g}$ was achieved at $\mathrm{pH}$ 3.0 , sorbent dosage $0.3 \mathrm{~g}$ in $50 \mathrm{~mL}$ (or $10 \mathrm{mg} / \mathrm{mL}$ ) during $30 \mathrm{~min}$ interaction and for $\mathrm{Cr}(\mathrm{VI}) 16.8 \mathrm{mg} / \mathrm{g}$ at $\mathrm{pH} 2.0$, sorbent dosage $0.7 \mathrm{~g}$ in $50 \mathrm{ml}$ (or $14 \mathrm{mg} / \mathrm{ml}$ ) during $45 \mathrm{~min}$ interaction. Biosorption equilibrium data for $\mathrm{Cr}(\mathrm{III})$ fit well the Langmuir model and for $\mathrm{Cr}(\mathrm{VI})$ and the Freundlich one. Kinetic studies reveal that $\mathrm{Cr}(\mathrm{III}) / \mathrm{Cr}(\mathrm{VI})$ biosorption by spirulina biomass could be described more favorably by the pseudo-second-order kinetic model. The process of $\mathrm{Cr}(\mathrm{III}) / \mathrm{Cr}(\mathrm{VI})$ biosorption was spontaneous and exothermic in nature. $\mathrm{Cr}(\mathrm{VI})$ biosorption from industrial effluent constituted $72 \%$ at $\mathrm{Cr}(\mathrm{VI})$ concentration in effluent $27 \mathrm{mg} / \mathrm{L}$, $\mathrm{pH} 4$, sorbent dosage $2.0 \mathrm{~g}$ and interaction time $45 \mathrm{~min}$.

\section{REFERENCES}

1. A. M. Zayed and N. Terry, Plant and Soil., 2003, 249, 139-156.

2. M. K. Gagrai, C. Das, A. K. Golder, Chemosphere, 2013, 93, 366-1371. 
3. M. Jagiełło, E. Minta, K. Chojnacka and P. Kafarski, Water Environ. Res., 2006, 78, 740-743.

4. E. Finocchio, A. Lodi, C. Solisio and A. Converti, Chem. Eng. J., 2010,156, 264-269.

5. M. Owlad, M. K. Aroua, W. A. W. Daud and S. Baroutian, Water Air Soil Poll., 2009, 200, 59-77.

6. H. Rezaei, S. D. Kulkarni and P. G. Saptarshi, Russ. J. Phys. Chem. A., 2012, 86, 1332-1339.

7. N. Ahalya, T. V. Ramachandra and R. D. Kanamadi, Res. J. Chem. Environ., 2003, 7, 71-79.

8. K. Chojnacka, A. Chojnacki and H. Gorecka, Chemosphere., 2005, 59, 75-84.

9. G. C. Donmez, Z. Aksu, A. Ozturk and T. Kutsal, Process Biochem., 1999, 34, 885-892.

10. A. Lodi, D. Soletto, C. Solisio and A. Converti, Chem. Eng. J., 2008, 136, 151-155.
11. M. K. Gagrai, C. Das and A. K. Golder, Can. J. Chem. Eng., 2013, 91, 1904-1912.

12. R. L. Babu, E. Vijayalakshmi, M .N. Kumar, R. H. Patil, K. S. Devaraju and S. Chidananda, Bioremediat. J., 2013, 17, 231-239.

13. G. Sibi, Green Energy Environ., 2016, 1, 172-177.

14. M. Lupea, L. Bulgariu and M. Macoveanu, Environ. Eng. Manag. J., 2012, 11, 607-615.

15. U. Guyo, N. Matewere, K. Matina, B. C. Nyamunda and M. Moyo, Bioremediat. J., 2017, doi: 10.1080/10889868.2017.1337710

16. I. Zinicovscaia, L. Cepoi, T. Chiriac, L. Rudi, O. A. Culicov, M. V. Frontasyeva, S. Pavlov, E. Kirkesali, S. Gundorina, T. Mitina, A. Akshintsev and E. Rodlovskaya, Desalin. Water. Treat., 2016, 57, 11103-11110. 
